\title{
FAKTOR - FAKTOR YANG MEMPENGARUHI KINERJA PERAWAT DALAM MELAKSANAKAN IMPLEMENTASI KEPERAWATAN DALAM MENINGKATKAN MUTU PELAYANAN DIRUMAH SAKIT
}

\author{
Sri Lailan Nazmi Saragih \\ Email : lailansaragih9@gmail.com
}

\begin{abstract}
ABSTRAK
Era globalisasi menuntut rumah sakit untuk meningkatkan mutu pelayanan kesehatan. Upaya meningkatkan mutu pelayanan kesehatan tak terlepas dari upaya meningkatkan mutu pelayanan keperawatan karena perawat merupakan tenaga kesehatan yang paling banyak jumlahnya di rumah sakit yang memberikan pelayanan secara kontinyu selama 24 jam. Mutu pelayanan keperawatan menggambarkan kinerja perawat. Kinerja seorang perawat dapat di nilai dari mutu asuhan keperawatan yang diberikan kepada pasien. Kinerja perawat dapat dipengaruhi oleh berbagai faktor diantaranya adalah motivasi, etos kerja, lingkungan kerja, kompetensi, kepuasan kerja. Tujuan dari jurnal ini adalah untuk mengetahui factor-faktor yang mempengaruhi kinerja perawat dalam melaksanakan implementasi keperawatan guna meningkatkan mutu pelayanan dirumah sakit.
\end{abstract}

Kata Kunci : Kinerja, Perawat, Implementasi

\begin{abstract}
Increasing the professionalism of a nurse's performance can be seen from the level education and training for nursing personnel that have been attended. Get reliable nursing personnel through improved performance nurses are determined by how the level of education of the nurse and often the nurse has nursing training. The results of research conducted by Awases (2009) on Affecting Factors Not all of the Performance of Professional Nurse in Namibia is obtained nurses who attend training can perform nursing actions based on the nursing process properly. This is possible due to less experience than the nurse herself, new or a guide inadequate and lack of confidence.
\end{abstract}

Key Words : Performance, Nurse, Implementation 


\section{LATAR BELAKANG}

Berdasarkan Undang-Undang Republik Indonesia Nomor 23 Tahun 1992 tentang Kesehatan, bahwa untuk mewujudkan derajat kesehatan yang optimal bagi masyarakat diadakan upaya kesehatan mencakup upaya peningatan kesehatan (promotif), pencegahan penyakit (preventif), penyembuhan penyakit (kuratif) dan pemulihan kesehatan (rehadolitatif) yang dilaksankan secara menyeluruh, terpadu, dan berkesinmabungan dan dilaksanakan bersama antara pemerintah dan masyarakat yang didukung oleh sumber daya kesehatan termasuk tenaga kesehatan. Tenaga kesehatan bertugas menyelenggarakan atau melakukan kegiatan pelayanan kesehatan yang berkualitas sesuai dengan bidang keahlian dan atau kewenangannya, salah satu di antaranya adalah tenaga keperawatan. Rumah Sakit merupakan salah satu komponen system pelayanan kesehatan yang mempunyai peranan penting dalam mening-katkan derajat kesehatan masyarakat. Beberapa tahun terakhir ini rumah sakit di Indonesia mengalami perkembangan, sejalan dengan kemajuan teknologi, ilmu pengetahuan dan sistem informasi. Peningkatan ini berdampak pada persaingan antar rumah sakit, sehingga rumah sakit saling berlomba untuk meningkatkan kualitas jasa pelayanan yang diberikan kepada masyarakat. Menghadapi era globalisasi saat ini, tuntutan kinerja pelayanan merupakan hal yang sangat penting. Rumah sakit harus memberikan pelayanan yang paripurna dan bermutu untuk dapat memberikan kepuasan kepada pasien sebagai pelanggannya. Issue strategis dalam perkembangan dan persaingan rumah sakit adalah peningkatan kinerja pelayanan dengan memberikan pelayanan yang berkualitas.

Pelayanan keperawatan merupakan bagian integral dari suatu kinerja pelayanan kesehatan. Profesi perawat sebagai pemberi pelayanan jasa berada digaris terdepan dan merupakan komponen yang sangat menentukan baik buruknya citra rumah sakit. Citra pelayanan kesehatan akan dinilai oleh customer berdasarkan kesan terhadap mutu pelayanan kesehatan keperawatan, selama menerima jasa pelayanan di rumah sakit. Dengan kata lain mutu asuhan keperawatan merupakan salah satu faktor penentu citra rumah sakit di mata masyarakat.

Gronross dalam Kotler (1997) mengatakan bahwa ada tiga unsur pokok yang saling berinteraksi dalam masalah mutu pelayanan terhadap kinerja yaitu pelanggan (customer), petugas pelayanan (customer service) dan manajeman (management). Salah satu hal yang penting dalam mencapai mutu pelayanan ialah kinerja petugas pelayanan dalam proses interaksi dengan pelanggan (pasien). Interaksi antara petugas dengan pasien merupakan hal yang sangat mendalam yang dirasakan pasien saat menerima pelayanan. Proses ini sangat dipengaruhi oleh perilaku petugas dalam melaksanakan pelayanan. Perbaikan mutu di rumah sakit melalui kinerja pelayanan kepada pasien pada umumnya dimulai oleh perawat melalui berbagai bentuk kegiatan, seperti gugus kendali mutu, penerapan 
standar asuhan keperawatan, pendekatan-pendekatan pemecahan masalah, maupun peningkatan kinerja keperawatan. Perawat sebagai suatu profesi harus dapat mempertahankan dan meningkatkan mutu asuhan keperawatan dengan standar. Standar merupakan level kinerja yang diinginkan dan dapat dicapai dimana kerja aktual dapat dibandingkan. Ia memberikan petunjuk kinerja mana yang tidak cocok atau tidak dapat diterima. Standar praktek keperawatan adalah pernyataan tentang apa yang dibutuhkan oleh registered nursed untuk dijalankan sebagai profesi keperawatan. Secara umum standar ini mencerminkan nilai profesi keperawatan dan memperjelas apa yang diharapkan profesi keperawatan dari para anggotanya. Dari beberapa uraian di atas berarti bahwa kinerja perawat sangat memegang peranan penting dalam meningkatkan mutu pelayanan keperawatan menuju pelayanan prima dan lebih khusus lagi untuk meningkatkan kinerja keperawatan di rumah sakit.

\section{METODE PENELITIAN}

Pengkajian ini menggunakan metode kualitatif yang dilakukan dengan cara mengumpulkan sebanyak-banyaknya data untuk dianalisis, yaitu dengan menggunakan literature view yang berkenaan dengan judul pembahasan yaitu mengenai factor-faktor yang mempengaruhi kinerja perawat dalam melaksanakan implementasi keperawatan guna meningkatkan mutu pelayanan dirumah sakit. Adapun Literature View yang digunakan adalah
Buku Teks, Buku Referensi, Jurnal Elektronik, Reasearch, dan hasil skripsi. Dengan kata kinerja, perawat, dan implementasi. Dan Literature View yang digunakan dalam metode ini adalah sebanyak 11 Literature View yang diterbitkan 8 tahun terakhir.

\section{HASIL}

Berdasarkan literature view yang saya baca, ada beberapa faktor yang mempengaruhi kinerja perawat dalam melaksanakan asuhan keperawatan.

A. Motivasi

Motivasi bertujuan untuk memberikan daya perangsang kepada karyawan yang bersangkutan agar perawat tersebut bekerja dengan segala daya dan upayanya (Manullang, 2004). Tujuan yang lebih lengkap dari motivasi adalah :

1. Meningkatkan moral dan kepuasan kerja perawat

2. Meningkatkan produktivitas kerja perawat

3. Mempertahankan kestabilan perawat

4. Meningkatkan loyalitas, kreativitas, dan partisipasi perawat

5. Mempertinggi rasa tanggung jawab perawat terhadap tugastugasnya dirumah sakit.

B. Fasilitas Kerja

Fasilitas adalah "suatu bentuk pelayanan perusahaan terhadap karyawan agar menunjang kinerja dalam memenuhi kebutuhan karyawan, sehingga dapat 
meningkatkan produktivitas kerja karyawan." (Husnan, 1992 dikutip dalam Hapsari, 2008).

Fasilitas kerja adalah sarana dan prasarana untuk membantu karyawan menyelesaikan pekerjaannya dan membuat karyawan bekerja lebih produktif. Kendala yang sering ditemukan dalam institusi rumah sakit adalah kendala fasilitas kerja yang kurang memadai yang mengakibatkan kinerja perawat juga menurun. Kesediaan fasilitas sangat mempengaruhi kinerja

seseorang, fasilitas merupakan penunjang kelancaran, seperti pelengkapan dan peralatan kerja, serta jaminan keselamatan kerja.

C. Fasilitas

Peningkatan profesionalisme kinerja seorang perawat dapat dilihat dari tingkat pendidikan dan pelatihan-pelatihan tenaga keperawatan yang pernah diikuti. Mendapatkan tenaga keperawatan yang handal melalui peningkatan kinerja perawat ditentukan oleh bagaimana tingkat pendidikan perawat tersebut dan seberapa sering perawat itu mengikuti pelatihan keperawatan. Hasil penelitian yang dilakukan oleh Awases (2009) tentang Factors Affecting Performance of Professional Nurse in Namibia didapatkan tidak semua perawat yang mengikuti pelatihan dapat melakukan tindakan keperawatan yang berdasarkan proses keperawatan dengan benar. Hal ini dimungkinkan akibat kurang pengalaman dari perawat itu sendiri, pedoman atau panduan yang kurang memadai serta kurang percaya diri.

\section{Imbalan Jasa}

Imbalan jasa adalah sesuatu yang dibayarkan atau pemenuhan dari suatu janji, reward, atau membalas jasa. Motivasi eksternal terbesar dari kinerja seseorang adalah imbalan jasa (Rahayu, 2008). Imbalan jasa yang layak akan memberikan rangsangan serta memotivasi karyawan untuk memberikan kinerja terbaik dan menghasilkan produktivitas kerja yang optimal (Suwatno, 2013). Sebaliknya menurut teori Victor Vroom dalam Suwatno (2013) yang menyatakan jika seseorang menginginkan sesuatu dan harapan untuk memperoleh sesuatu itu cukup besar, yang bersangkutan akan sangat terdorong untuk memperoleh hal yang diinginkannya itu. Sebaliknya jika harapan itu tipis, motivasinya untuk berupaya akan menjadi rendah.

\section{PEMBAHASAN}

Kinerja sebagai hasil-hasil fungsi pekerjaan/kegiatan seseorang atau kelompok dalam suatu organisasi yang dipengaruhi oleh berbagai factor untuk mencapai tujuan organisasi dalam periode waktu tertentu (Pabundu, 2006). Sedangkan Mangkunegara (2009) Kinerja (prestasi kerja) adalah hasil kerja secara kualitas dan kuantitas yang dicapai seorang pegawai dalam 
melaksanakan tugasnya sesuai dengan tanggung jawab yang diberikan kepadanya. Menurut Prawirosentono, kinerja atau performance adalah usaha yang dilakukan dari hasil kerja yang dapat dicapai oleh seseorang atau sekelompok orang dalam suatu organisasi sesuai dengan wewenang dan tanggung jawab masing-masing dalam rangka mencapai tujuan organisasi bersangkutan secara legal, tidak melanggar hukum dan sesuai dengan moral maupun etika (Usman, 2011).

\section{Motivasi dengan Kinerja Perawat}

Menurut Sbortell \& Kaluzny (dikutip dalam Mustikasari, 2010), motivasi adalah perasaan atau pikiran yang mendorong seseorang melakukan pekerjaan atau menjalankan kekuasaan terutama dalam berperilaku. Perawat yang motivasi kerja pada kategori rendah sebagian besar terdistribusi pada kinerja kurang $(71,9 \%)$, dimana angka pencapaian ini tidak dapat memberi interpretasi bahwa motivasi dapat meningkatkan kualitas kerja, yang dilaksanakan perawat dalam rangka penyelenggaraan asuhan keperawatan dengan hasil yang maksimal dan memuaskan kebutuhan pasien dan keluarganya.

2. Kepemimpinan dengan Kinerja Perawat

Kepemimpinan merupakan seni untuk seorang pemimpin dalam melayani orang lain untuk memberikan apa yang dimiliki untuk kepentingan orang lain
(Nurachmah, 2009). Sebagai pemimpin, hendaknya seseorang menempatkan dirinya sebagai orang yang bermanfaat untuk orang lain. Hasil penelitian menunjukkan bahwa perilaku kepemimpinan pada kategori kurang baik $(74,2 \%)$ dengan kinerja perawat yang kurang baik pula. Hal ini tidak memberikan intepretasi tentang kemampuan pemimpin dalam menjalankan tugas dan tanggung jawabnya. Kemudian diperoleh juga hasil perilaku kepemimpinan baik dengan kinerja perawat kategori kurang. Kepemimpinan dalam bidang keperawatan merupakan salah satu faktor penting karena faktor kepemimpinan dapat memberikan pengaruh yang berarti terhadap kinerja perawat karena pimpinan yang merencanakan, menginformasikan, membuat, dan mengevaluasi berbagai keputusan yang harus dilaksanakan dalam organisasi tersebut. Kepemimpinan dapat memotivasi perawat untuk bekerja dengan penuh semangat sehingga hasil yang ingin dicapai dapat memuaskan perawat maupun rumah sakit.

3. Status Pelatihan dengan Kinerja Perawat

Pelatihan merupakan proses pendidikan jangka pendek menggunakan prosedur sistematis dan terorganisir yang pernah diikuti oleh responden dengan tujuan meningkatkan mutu, keahlian dan kemampuannya sehingga terampil dalam melaksanakan tugas. Hasil 
pengamatan dilapangan bahwa perawat yang pernah mengikuti pelatihan dengan kinerjanya cukup baik disebabkan karena pelatihan tentang asuhan keperawatan pernah diikuti sesuai dengan tugasnya. Perawat yang pernah mengikuti pelatihan dengan kinerjanya kurang baik disebabkan karena materi pelatihan yang diberikan tidak sesuai dengan tugasnya sehingga apa yang diperoleh tidak cocok diterapkan dalam seksinya ( Handoko, 2011). Factors Affecting Performance of Professional Nurse in Namibia didapatkan tidak semua perawat yang mengikuti pelatihan dapat melakukan tindakan keperawatan yang berdasarkan proses keperawatan dengan benar. Hal ini dimungkinkan akibat kurang pengalaman dari perawat itu sendiri, pedoman atau panduan yang kurang memadai serta kurang percaya diri

4. Imbalan jasa dengan Kinerja Perawat

Imbalan jasa adalah sesuatu yang dibayarkan atau pemenuhan dari suatu janji, reward, atau membalas jasa. Motivasi eksternal terbesar dari kinerja seseorang adalah imbalan jasa (Rahayu, 2008).

Menurut penelitian Harapan (2004), yang bertujuan untuk mengidentifikasi tentang kepuasan kerja dan hubungannya dengan kinerja perawat tetap baik dalam memberikan asuhan keperawatan di Rumah Sakit Permata Bunda, menginformasikan imbalan jasa yang diterima perawat rendah namun kinerjanya tetap baik karena individu bekerja bukan sematamata hanya untuk menerima imbalan jasa saja tetapi juga untuk mencari kepuasan kerja tersendiri.

\section{KESIMPULAN}

Mutu pelayanan keperawatan menggambarkan kinerja perawat. Kinerja seorang perawat dapat di nilai dari mutu asuhan keperawatan yang diberikan kepada pasien. Kinerja perawat dapat dipengaruhi oleh berbagai faktor diantaranya adalah motivasi, etos kerja, lingkungan kerja, kompetensi, kepuasan kerja.

\section{SARAN}

Untuk seorang perawat agar lebih meninmgkatkan kinerja nya dalam menjalankan tugas. Hal ini dapat meningkatkan kepuasan pasien, dan mutu rumah sakit tempat dimana perawat bekerja. 


\section{DAFTAR PUSTAKA}

Bawono, D. C., \& Nugraheni, R. (2015). Analisis Pengaruh Pemberian Insentif , Kepemimpinan , dan Beban Kerja Terhadap Kinerja Perawat. Diponegoro Journal of Management, 4(3), 3.

Butar-Butar, J., \& Simamora, R. (2016). Hubungan Mutu Pelayanan Keperawatan dengan Tingkat Kepuasan Pasien Rawat Inap di RSUD Pandan Kabupaten Tapanuli Tengah. Jurnal Ners Indonesia, 6(1), 50-63.

Desrison, \& Ratnasari, S. L. (2018). Faktor yang mempengaruhi Kinerja Perawat di Instlasi Rawat Inap RSUD Sawah Lunto (Vol. 5).

Mahyar, S., Ermawati, \& Rusmiyati. (2013). Konsep Dasar Keperawatan. JAKARTA: TIM.

Maimun, N., \& Yelina, A. (2016). Kinerja Keperawatan di Rumah Sakit Bhayangkara Pekan Baru. Jurnal Kesehatan Komunitas, 3(2).

Mandagi, F. M., Umboh, J. M., \& Rattu, J. A. (2015). Analisis Faktor-Faktor yang berhubungan dengan kinerja Perawat dalam Menerapkan Asuhan Keperawatan di Rumah Sakit Umum Bethesda GMIM Tomohon (Vol. 3).
Markuis, B. (2010). Kepemimpinan dan Manajemen Keperawatan (4 ed.). JAKARTA: EGC.

Notoatmodjo, S. (2012). Metodelogi Penelitian Kesehatan . Jakarta: Rineka Cipta.

Ratanto, Sari, M., \& Kuntarti. (2013). Pengembangan Karier Sebagai Faktor Paling Mempengaruhi Kinerja Perawat Pelaksana (Vol. 16).

Rebanti, L. J., Untari, J., \& Agni, M. G. (2017). Faktor - Faktor yang Berhubungan Dengan Tingkat Kinerja Perawat di Ruang Rawat Inap RSUD Panembahan Senopati Bantul (Vol. 2).

Sabarulin, Darmawansyah, \& Abdullah, R. (2013). Faktor yang Mempengaruhi Kinerja Perawat dalam Mendokumentasikan Asuhan Keperawatan di Rumah Sakit Woodward Palu (Vol. 2).

Simamora, R. (2005). Hubungan Persepsi Perawat Pelaksana Terhadap Penerapan Fungsi Pengorganisasian yang Dilakukan Oleh Kepala Ruangan Dengan Kinerjanya Diruang Rawat Inap RSUD Koja Jakarta Utara (Doctoral dissertation, Tesis FIK UI, Tidak dipublikasikan) 